\title{
Taxation and female labor supply in Italy
}

\author{
Fabrizio Colonna ${ }^{1}$ and Stefania Marcassa ${ }^{2 *}$
}

\author{
*Correspondence: \\ stefania.marcassa@u-cergy.fr \\ ${ }^{2}$ Université de Cergy-Pontoise \\ THEMA (UMR CNRS 8184), 33 \\ boulevard du Port, 95011 \\ Cergy-Pontoise cedex, France \\ Full list of author information is \\ available at the end of the article
}

\begin{abstract}
Italy has the lowest labor supply of married women among EU countries. Moreover, the participation rate of married women is positively correlated with their husbands' income. We show that these two features can be partly explained by the tax system: a high tax rate together with tax credits and transfers raise the burden of two-earner households, generating disincentives to work. We estimate two structural models of labor supply: one where the husband's labor supply is inelastic and one with joint couple decisions. Then we use the estimated parameters to simulate the effects of alternative revenue-neutral tax systems on labor supply. We find that working tax credit and gender-based taxation boost it, with the effects of the former being concentrated on low educated women. Conversely, joint taxation implies a drop in the participation rate.

JEL codes: J21, J22, H31

Keywords: Female labor force participation; Italian tax system; Second earner tax rate; Joint taxation; Gender-based taxation; Working tax credit
\end{abstract}

\section{Springer}

\section{Introduction}

The labor force participation of Italian married women is about 60 percent, the lowest percentage among EU countries. Furthermore, their participation rate is markedly increasing by percentile of husband's earnings. We argue that the taxation system partly explains the coexistence of these two features.

Even thought the influence of the taxation system is not necessarily the first mechanism that comes to mind when thinking about labor supply, there are several reasons that point to its relevance. First, the unusual positive correlation between participation rate and husband's income leads us to exclude mechanisms which would affect all households in a similar way. Second, in Italy, the individual (not the household) constitutes the basic unit of taxation. This implies that the first euro of earned income for a married woman is taxed as the first euro of the husband's income, and not as the last euro like in countries where joint filing is allowed. Third, the tax system is characterized by a set of tax credits and cash transfers for children and non-working spouses, which are decreasing functions of the household income.

The combination of these elements raises the tax burden, especially on two-earner households, generating disincentives to participate in the labor force for married women who are typically the second earner of the family. Such disincentives are stronger when the

(c) 2015 Colonna et al.; licensee Springer. This is an Open Access article distributed under the terms of the Creative Commons Attribution License (http://creativecommons.org/licenses/by/4.0), which permits unrestricted use, distribution, and reproduction in any medium, provided the original work is properly credited. 
first earner's income is low. More specifically, the incidence of tax credits and universal cash transfers on the second earner tax rate decreases in total income, providing incentives to participate that are higher for richer households ${ }^{1}$. Concretely, the second earner tax rate reaches a maximum at low levels of husbands' yearly earnings, namely 8,000 euros for childless couples, and 19,000 euros for couples with children. The overall effect of this design is that earnings of married women decrease the amount of transfers received by the households when they enter the labor market, primarily discouraging participation, but also part-time and low skill jobs ${ }^{2}$.

We propose a simple theoretical model to convey the main testable implications. Then, we use micro data from the EU-SILC (2007-2011) to estimate two more complex structural models of labor supply that take into account the participation decision of married females in two-earner households, as well as its interplay with the structure of heterogeneity and taxation. In the benchmark model, men's labor supply is exogenous, while in the extended model, couples take decisions simultaneously. In both models household non-labor income is given, and the labor supply decision is taken sequentially: each partner decides whether to search for a job, and upon receiving an offer, to accept it or not. Participation decisions depend on the net yearly income and are therefore affected by the characteristics of the taxation system. The models are able to reproduce the low participation rate of Italian women as well as the positive correlation between wives' participation rate and husbands' income. They also match the part-time and full-time employment rates.

We use our framework to conduct three hypothetical (revenue-neutral) tax reform experiments and then ask: what is the importance of the labor-supply responses of married women? We concentrate on joint family taxation (in line with the French system), gender-based taxation (as proposed by Alesina et al. (2011)), and a system inspired by the (British and American) working tax credit ${ }^{3}$. The simulated tax systems are characterized by the same taxation rates but differ in the set of tax credits and transfers. Our work suggests that these alternative systems could boost women's participation up to at most 4 percentage points and increase part-time employment by 2 percent. In particular, the working tax credit and the gender-based system raise the labor supply of all women. The effects of the former concentrates on low educated women, and hence, on low skill and part-time jobs. The reason is that in-work transfers are means of passing income towards low revenue families conditional on working, incentivizing work and avoiding poverty traps implied by excessive marginal tax rates. In the gender-based system, the reduced tax burden generates a positive shift of the participation rate. But the tax credits for dependent spouses and children leave unchanged the negative incentives for low-income households. By contrast, we show that joint taxation implies a substantial drop in the participation of married women and a negative correlation between participation rate and husband's income.

Finally, to assess the welfare effects from our experiments, we compute the Gini coefficient and several poverty measures. We show that the gender-based system increases the well-being of all households, reducing the transfers needed to reach the poverty line.

Related literature Our paper is connected to three strands of literature. First, it relates to recent works which argue that the taxation system may create a set of incentives for labor 
force participation and that it plays an important role in explaining cross-country differences in labor supply behavior. Some examples are Prescott (2004), Davis and Henrekson (2004), Rogerson (2006), and Olovsson (2009).

Second, our work belongs to the rich stream of empirical literature on labor supply. A fundamental role in addressing the relevance of taxation has been played by Burtless and Hausman (1978), Hausman (1980), and Hausman (1985). Another important paper in this branch is the one by Colombino and Del Boca (1990). We enrich their results by showing that the model is able to reproduce the positive correlation between wife's labor force participation rate and husband's income.

Third, several studies examine the effect of tax reforms on labor force participation. Up to twenty years ago, the theoretical literature on optimal taxation converged to a scenario characterized by a basic income transfer and an almost flat income tax. More recently, the literature focused on in-work benefits (Aaberge et al. (2000), Saez (2002), Immervoll et al. (2007), Mooij (2008), and Blundell et al. (2011)). Several studies have evaluated the expected labor supply effects from introducing in-work tax credits in the U.S. and U.K. The most recent and relevant studies are (Blundell et al. (2000) and Blundell and Hoynes (2004) for the U.K., and Meyer and Rosenbaum (2001) and Fang and Keane (2004)) for the U.S. They show that there are strong incentive effects from tax credits. The broadening of the tax credit seems to have contributed to the increase in labor force participation and to have reduced welfare. We find that their outcomes also apply to Italy. Our results are also consistent with the findings of Eissa and Liebman (1996), Cavalli and Fiorio (2006), and Bar and Leukhina (2009).

The paper is organized as follows. In Section 2, we provide some empirical evidence that motivates the choice of Italy. We describe the Italian taxation system and propose a simple theoretical model. In Section 3, we specify the empirical strategy, we describe the data, and present the results. In Sections 4 and 5, we measure the behavioral effects of alternative tax systems. Section 6 concludes.

\section{Labor market and taxation system in Italy}

\subsection{Empirical evidence}

In this section, we describe the main characteristics of the Italian labor market in 20072011 and how it differs from the other EU-SILC countries, especially Spain ${ }^{4}$. In Table 1, we can see that, on average, about 74 percent of women aged 26-54 years old are employed. The number is over 83 percent for men.

There are large cross-country differences in the gender gap, which is about 9 percent on average, and 13 percent for Spain. Italy stands out for a gender employment gap of almost 20 percentage points and for one of the lowest employment rates of women, which is about 16 percentage points lower than the average and 9 percentage points lower than Spain $^{5}$.

Table 1 Employment Rates for 26-54 years old, by gender, 2007-2011

\begin{tabular}{|c|c|c|c|c|c|c|}
\hline & \multicolumn{3}{|c|}{ Men } & \multicolumn{3}{|c|}{ Women } \\
\hline & Total & Full-time & Part-time & Total & Full-time & Part-time \\
\hline Average & 83.13 & 80.69 & 2.48 & 74.53 & 62.18 & 12.41 \\
\hline Italy & 76.45 & 73.47 & 3.02 & 58.38 & 44.02 & 14.39 \\
\hline Spain & 80.01 & 77.02 & 3.00 & 67.40 & 53.69 & 13.73 \\
\hline
\end{tabular}

Source: Authors' computations from EU-SILC data (2007-2011). 
There are also gender gaps in the intensity of employment participation. In almost all of the countries, a much larger share of female employment is part-time when compared to male employment, with an average of 12 percent for women and only 2 percent for men. While both full- and part-time employment rates of Italian men are in line with the European average, the full-time rate of Italian women seems to depress their total rate. The importance of part-time employment for women has been at the center of numerous debates among academic economists and policy makers. In 2003, the Italian government approved a law that aimed to increase the flexibility of the existing part-time legislation, having only a limited impact on the difference in part-time employment with other countries ${ }^{6}$.

The gender gap is very large in the general participation rate, as shown in Table 2. Italy has one of the lowest participation rates of women and a gender participation gap of about 16 percentage points against an average gap of 10 percentage points ${ }^{7}$.

The marital status considerably affects the decision to participate, with married women having a participation rate that is 10 percentage points lower than unmarried women. This gap is particulary strong in Italy, where it reaches about 15 percentage points. Moreover, participation rates tend to be lower for mothers. On average, 75 percent of married mothers are in the labor force, but only 59 percent in Italy.

Another important feature of the Italian labor market can be observed in Figure 1, where we can see that the labor force participation of married women is positively correlated to their husbands' yearly income. More specifically, the participation rate is below 55 percent for husband's yearly gross labor earnings lower than 20,000 euros (second percentile); it increases up to about 70 percent at husbands' earnings of 30,000 euros (sixth percentile) to remain at that same level in correspondence of the highest percentiles of income.

This is in contrast with the other countries, including Spain, where the labor force participation appears to be inelastic. To the best of our knowledge these characteristics of the Italian labor force participation of married women has not been explored in the literature, and it is one of the facts that strongly motivated our project. In particular, we argue that the Italian taxation system provides a system of disincentives that makes low-income households choose to remain out of the labor force in order to receive tax credits and cash transfers.

To get a measure of the correlation between the labor force participation of married women and the various demographic variables available in the EU-SILC dataset, we run a simple probit regression of this kind:

$$
\operatorname{Pr}(Y=1 \mid X)=\Phi\left(X^{\prime} \beta\right),
$$

Table 2 Labor force participation for 26-54 years old, 2007-2011

\begin{tabular}{lccccccc}
\hline & & & \multicolumn{2}{c}{ Married women } & & \multicolumn{2}{c}{ Unmarried women } \\
& Women & Men & w/children & w/o children & & w/children & w/o children \\
\hline Average & 78.99 & 87.43 & 75.04 & 77.28 & & 83.20 & 86.87 \\
Italy & 65.99 & 82.56 & 58.72 & 61.33 & & 74.62 & 80.76 \\
Spain & 75.34 & 86.53 & 69.16 & 67.39 & & 83.08 & 89.41 \\
\hline
\end{tabular}

Source: Authors' computations from EU-SILC data (2007-2011). 


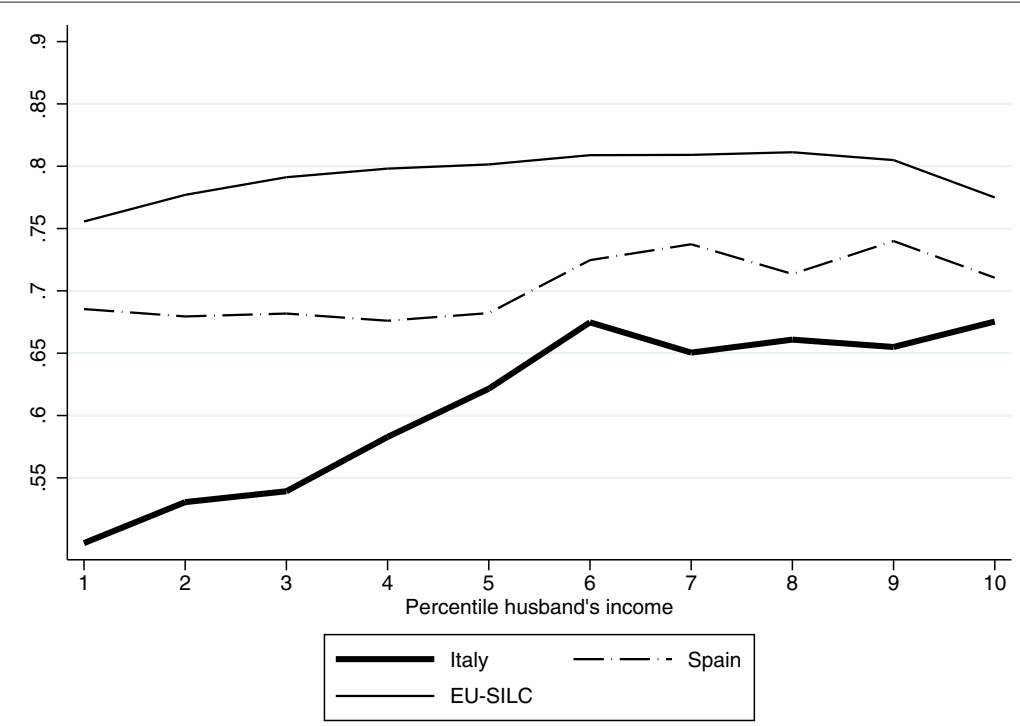

Figure 1 Labor force participation of women by percentile of husband's income. Source: Authors' computations from EU-SILC data (2007-2011).

where $\operatorname{Pr}(Y=1 \mid X)$ denotes the conditional probability of participating in the labor market, $\Phi$ is the cumulative distribution function of a standard normal distribution, and the vector of parameters $\beta$ is estimated by maximum likelihood ${ }^{8}$.

We allow the propensity scores to depend on the woman's marital status, on the husband's employment status, and his yearly gross earnings if she is married. Moreover, we control for some demographic characteristics such as the presence of children, age, education level, and household non-labor income. We also add year fixed effects. We run a separate regression for Italy and the rest of the countries considered in our data analysis. Results are in Table 3. Table 14 in Additional file 1: Appendix C reports the marginal effects of the control variables for all the EU-SILC countries.

The signs of the marginal effects on the usual demographic variables are consistent across countries. While the data for the EU and Spain satisfy the standard income pooling hypothesis, showing a negative correlation between husband's earnings and labor force participation, Italy behaves differently. That is, a significant positive marginal effect of 0.021 characterizes Italian data, versus a negative coefficient of 0.020 for the average of the countries, or 0.039 for Spain. These numbers imply that a 1 percent increase in husband's earnings decreases the probability of participating in the labor force by 3.9

Table 3 Probit - marginal effects

\begin{tabular}{lcccccc}
\hline & $\begin{array}{c}\text { Husband's } \\
\text { earnings }\end{array}$ & $\begin{array}{c}\text { Household } \\
\text { non-labor income }\end{array}$ & Controls & Year fixed effects & Log likelihood & Obs. \\
\hline EU-SILC & $-0.020^{* * *}$ & $-0.026^{* * *}$ & YES & YES & -109533.990 & 238189 \\
& $(0.001)$ & $(0.000)$ & & & & \\
Italy & $0.021^{* * *}$ & $-0.016^{* * *}$ & YES & YES & -12111.044 & 19361 \\
& $(0.006)$ & $(0.003)$ & & & & \\
Spain & $-0.039^{* * *}$ & -0.002 & YES & YES & -5759.401 & 10392 \\
& $(0.008)$ & $(0.002)$ & & & & \\
\hline
\end{tabular}

Robust standard errors in parentheses. ${ }^{* * *} \mathrm{p}<0.01,{ }^{* *} \mathrm{p}<0.05,{ }^{*} \mathrm{p}<0.1$.

Source: Authors' computations from EU-SILC data (2007-2011). 
percent in Spain, but it increases it by 2.1 percent in Italy. Such results are particularly surprising because we would expect household income pooling to discourage women from participating in the labor market, especially for those married to high income husbands. Interestingly, this anomaly is not observed for the non-labor household income, which negatively impacts the probability to participate in all countries?.

In summary, the Italian labor market exhibits distinctive features. There is a disparity between men and women in the participation rate, mainly regarding married couples. Moreover, once employed, Italian women are much less likely to have a full-time jobs than in other European countries. In what follows, we bridge these facts to the Italian tax system.

\subsection{The Italian tax system}

In this section, we describe the main characteristics of the Italian taxation system. More technical details can be found in Additional file 1: Appendix A.

We define the second earner of a household as the worker with the second highest income in the family ${ }^{10}$. Generally, in a married couple, the husband is considered to be the first earner who participates in the labor market with certainty. The wife is the second earner. Her decision to participate depends on several economic and non economic variables ${ }^{11}$. In particular, it depends on the fraction of her expected gross income that will be disposable, net of total taxes. To understand the impact of taxes on the decision to work, we make use of the concept of the second earner tax rate, a tax rate on labor force participation, as in Eissa et al. (2005).

Let us define the second earner tax rate (SET) as follows:

$$
\mathrm{SET} \equiv \frac{\Delta \operatorname{Tax}}{w_{f}}=\frac{\operatorname{Tax}\left(w_{m}, w_{f}\right)-\operatorname{Tax}\left(w_{m}, 0\right)}{w_{f}}
$$

where $\operatorname{Tax}\left(w_{m}, w_{f}\right)$ and $\operatorname{Tax}\left(w_{m}, 0\right)$ are the total income taxes paid by the household if the wife works and if she does not work, respectively. $w_{f}$ is her gross income when she works, and $w_{m}$ is the husband's gross income. We assume that her income is equal to zero when she does not work (i.e., she is either out of the labor force or unemployed).

Now, depending on the unit of the fiscal system (individual or family), the second earner tax rate and the average tax rate of a married woman may be significantly different than those of an unmarried woman ${ }^{12}$. In Italy, however, we should not observe a marital status dependence of the amount of tax paid because the tax system is based on the individual and not on the household. Nevertheless, tax credits for family dependents and universal cash transfers for children are decreasing functions of the household income and indirectly affect the fiscal burden related to the labor force participation status of the wife. Hence, the SET can be expressed as the sum of taxes on the wife's individual labor income $T\left(w_{f}\right)$ and the change in household-based transfers $F\left(w_{m}, w_{f}\right)$ in the following way:

$$
\mathrm{SET}=\frac{T\left(w_{f}\right)}{w_{f}}+\frac{F\left(w_{m}, 0\right)-F\left(w_{m}, w_{f}\right)}{w_{f}}
$$

Since 2007, the tax system grants a tax credit for dependent spouses who earn less than $2,840.51$ euros a year, a very low labor income. The amount of tax credits for dependent 
spouses varies between 0 and 730 euros depending on the total household income. To better understand the incidence of the distortion, consider the following examples:

(1) Assume that an unmarried woman (not currently employed) receives an offer to work part-time earning 7,200 euros a year. As the current taxation system includes a no-tax area for yearly income lower than 8,000 euros, her net disposable income would increase by 7,200 euros a year. She would pay a SET of 0 .

(2) Assume now that this same woman is married to an employed man earning 35,000 euros a year. The tax credit system would grant 720 euros to the household if she did not work. If she were to accept the job offer, she would not depend on the husband anymore, and he would not receive the tax credit. The household disposable income would not increase by 7,200 euros a year, but by 6,480 euros a year, i.e. $(7,200-720)$. She would pay a SET equal to 10 percent $(720 / 7,200)$.

(3) Assume the husband earns 50,000 euros a year. The tax credit system would grant 517.50 euros to the household if she did not work. She would pay a SET equal to 7.18 percent $(517.50 / 7,200)$.

(4) Assume the husband earns 100,000 euros a year. He would not receive the tax credit and the SET would be zero.

These examples show that the amount of tax credits decreases with the total household income, and it is zero for incomes higher than 95,000 euros a year. The universal cash transfers for children put a similar mechanism at work in married households. On the contrary, they have the positive effect of reducing the fiscal burden of unmarried mothers and create positive incentives to their participation rate (as in example (1)).

Figure 2 plots the SET on earnings of women for different levels of gross yearly earnings. The figures in the left column plot the SET against women's gross yearly earnings at a

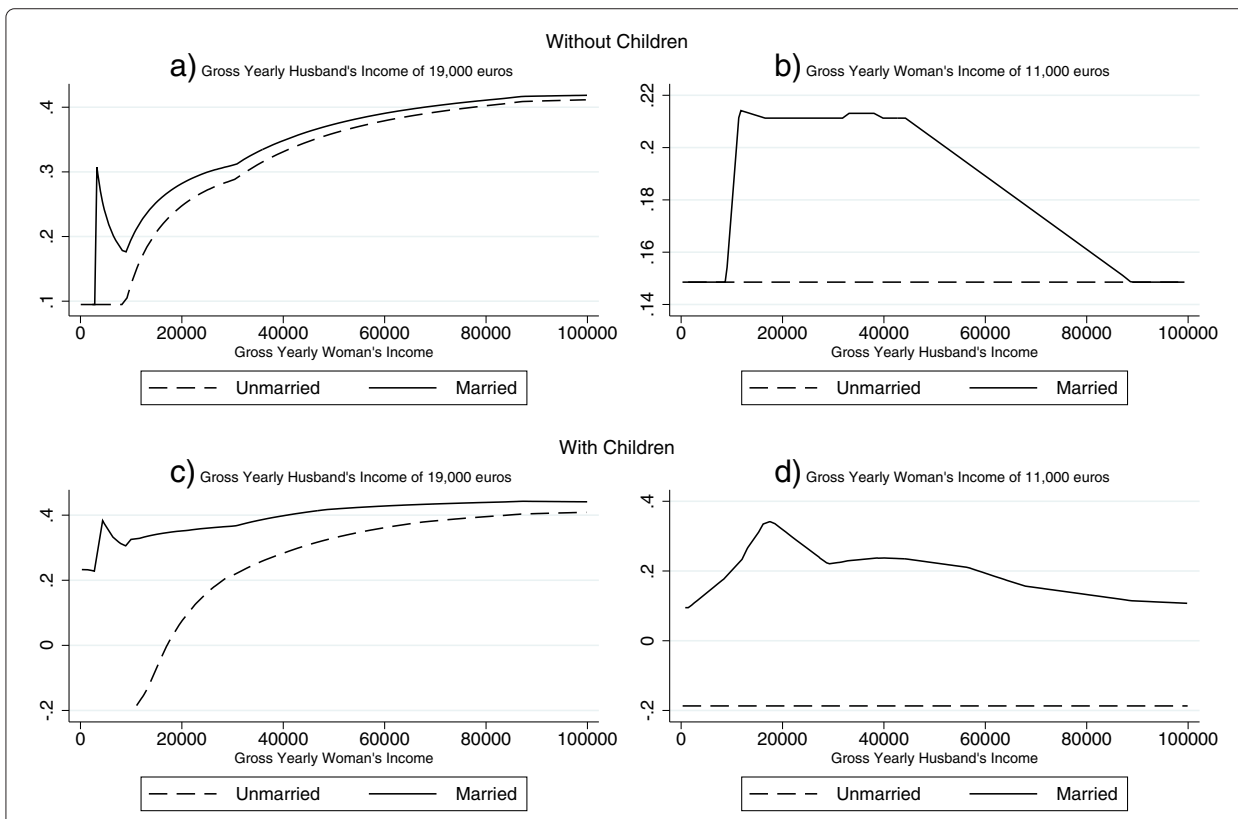

Figure 2 Second earner tax rate by marital status. Source: authors' simulations. 
given level of husbands' gross yearly earnings of 19,000 euros. The figures in the right column plot the SET on earnings against husbands' gross yearly earnings at a level of women's gross yearly earnings of 11,000 euros ${ }^{13}$. The top panel is for women without children, and the bottom panel is for women with two dependent children.

In panel a), we can see that the married-unmarried difference in SET is particularly relevant for low women's earnings (less than 4,000 euros) and dies down as the income increases. The pick of the SET of married women occurs in correspondence with yearly earnings of about 3,500 euros. At that point, husbands are not entitled to receive a tax credit for dependent spouses, and the SET jumps from 9 to about 30 percent. These couples face a trade-off between having the wife participating in the labor market earning a very low salary and not receiving tax credits (but still increasing the total household income) versus not participating and paying lower taxes (because of the tax credits).

In panel b), the SET of married women is constant and equal to the one of unmarried women until a level of husband's income of about 8,000 euros. In the interval $[0,8,000]$ euros, the husband's income belongs to the no-tax area, and only his wife's earnings are subject to taxation. After that point, both incomes are taxed and the SET increases to about 20 percent. It is worth noting that the SET remains high for medium levels of household incomes to decrease and reach the second earner tax rate of unmarried women for husbands' earnings in the highest percentiles.

In panel c) and d), we plot the SET of households with children. We can see that (low earnings) unmarried mothers are subject to negative taxation, as they are eligible for universal cash transfers for dependent children which are higher than the amount of taxes that they are supposed to pay. Married mothers are subject to a higher SET because of the (lower) amount of universal cash transfers for dependent children agreed to the husband. The SET reaches a peak of 40 percent for wife's earnings of about 3,200 euros. As in panel a), the difference between the tax paid by married and unmarried women decreases with their earnings. In panel d), we can see more clearly the impact of the universal cash transfers for dependent children. The SET of married mothers is increasing up to yearly gross husband's earnings of about 19,000 euros. After that point, the decreasing cash transfers for dependent children and spouses diminish the difference between taxes to pay if working or not working.

Now, we take a closer look at the impact of taxes by marital status in Figure 3. In panel a), we observe that unmarried women with children have a SET which is much lower than that of unmarried women without children, as the former receive cash transfers for the dependent children. On the contrary, for married women (panel b)), the presence of children negatively affects the SET. Comparing the levels of SET between married and unmarried women by presence of children, we observe that the difference is significatively positive for low-income mothers whose husbands are entitled to receive tax credits and transfers. But it is very close to zero for higher incomes and, in general, for childless women.

In summary, the Italian tax system, even if based on individuals and not on households, generates a set of negative incentives to female labor force participation. This is due to universal cash transfers and tax credits for dependent children and spouses that increase the second earner tax rate of married relative to unmarried women. The distortion is increasing with the number of children and reaches a maximum at a level of husband's 

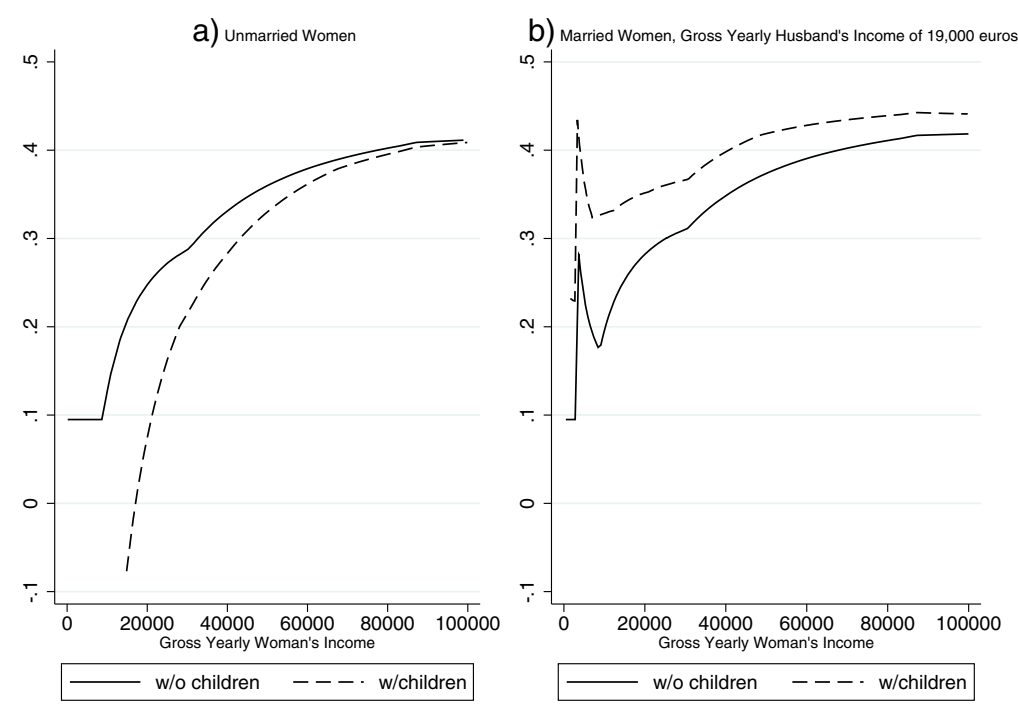

Figure 3 Second earner tax rate by marital status and presence of children. Source: authors' simulations.

gross yearly earnings of about 8,000 euros for childless couples and 19,000 euros for couples with children.

\subsection{Theoretical model}

We outline a simple static labor supply model to show how some characteristics of the Italian taxation system might relate to the unusual negative correlation between labor force participation of married women and their husbands' income discussed above. The complete and more complex empirical model will be derived in the next section.

We consider the discrete choice problem of a woman who, upon receiving a job offer, must decide whether to work at wage $w_{f}{ }^{14}$. We assume that her utility is separable in household income and leisure. Following the previous notation, we distinguish between $T(w)$, the gross tax schedule based on individual labor income $w$, and $F\left(w_{m}, w_{f}\right)$, the transfers granted to employed workers based on total household income, such as tax allowances for dependent spouses and cash transfers for dependent children. We assume that $T^{\prime}>0, T^{\prime \prime} \geq 0, F^{\prime}<0$ and $F^{\prime \prime}<0$. These assumptions are justified by the fact that fiscal systems are typically progressive, i.e., the marginal tax rate is increasing in income and the tax credit is granted only to families with an income below a given threshold.

The problem of an unmarried woman can therefore be described as the choice between two utility levels:

$$
U= \begin{cases}\alpha & \text { if she stays out of the labor force (or unemployed), } \\ w_{f}-T\left(w_{f}\right)+F\left(0, w_{f}\right) & \text { if she works, }\end{cases}
$$

where $\alpha$ denotes her leisure utility and her unemployment income is normalized to 0 . Similarly for a married woman:

$U= \begin{cases}w_{m}-T\left(w_{m}\right)+F\left(w_{m}, 0\right)+\alpha & \text { if she stays out of the labor force (or unemployed), } \\ w_{m}+w_{f}-T\left(w_{m}\right)-T\left(w_{f}\right)+F\left(w_{m}, w_{f}\right) & \text { if she works, }\end{cases}$ 
with $w_{m}$ denoting her husband's gross earnings. A woman will work if her value of leisure $\alpha$ is higher than the net benefit from employment

$$
\begin{aligned}
& \alpha \geq w_{f}-\left[T\left(w_{f}\right)-F\left(0, w_{f}\right)\right] \text { if she is unmarried, } \\
& \alpha \geq w_{f}-\left\{T\left(w_{f}\right)-\left[F\left(w_{m}, 0\right)-F\left(w_{m}, w_{f}\right)\right]\right\} \text { otherwise. }
\end{aligned}
$$

By comparing (4) and (5), we observe that married women face a higher second earner tax: it includes not only the gross tax $T\left(w_{f}\right)$ but also the potential drop in transfers granted to her husband $F\left(w_{m}, 0\right)-F\left(w_{m}, w_{f}\right)$. Moreover, such an effect is larger for a low-income worker's spouse: since $F^{\prime \prime}<0$, and the additional implicit taxation $F\left(w_{m}, 0\right)-F\left(w_{m}, w_{f}\right)$ is decreasing in $w_{m}$. Intuitively, a rich husband will not benefit from any transfer, no matter what the employment status of his wife is.

\section{Estimation and results}

\subsection{The models and the empirical specifications}

Our policy evaluation methodology relies on a static microeconometric labor supply model. We extend the simple theoretical framework presented in the previous section in order to encompass workers' and jobs' heterogeneity and include labor market participation choice ${ }^{15}$. The key feature of our modeling framework is the exact representation of tax and transfer schemes when estimating the model.

It is important to underline that we will report several simulation results in relation with the marital status of the agents. That is: (i) the implied choices of unmarried men and women, separately estimated; and (ii) the simultaneous choices of spouses. For case (ii), we will show the differences in the elasticities of women's probability of participation both when husband's participation choice is taken as given (as in (Kleven et al. 2009)) and when it is endogenous. Note that in the case of inelastic husband's labor supply, women solve a similar problem to that of unmarried women, where husband's employment status and earnings are taken into account.

We build a two-stage static model of labor supply. Consider a one-person decision problem $^{16}$. In the first stage, an agent decides whether to join the labor market and search for a job. If she does, she enters the second stage and receives, for each possible amount of working time $h \in H \subset \mathfrak{R}^{+}$, a job offer characterized by a level of gross yearly earnings $w(h)$. She can accept one of them or reject them all and stay unemployed $(h=0)$. The problem is discretized in the sense that the choice of hours is supposed to be made between few alternatives: part-time, full-time, or unemployment. The idea is simply that there generally are commonly agreed durations of work in the labor market, including the possibility not to work at all. This is relatively realistic and particularly appropriate in the case of Italy where social and institutional norms as well as demand-side rigidities are strong and imply concentrations around a limited number of hour choices. Thus, when modeling unmarried individuals or inelastic husband's labor supply, the set of alternatives ( $h=1, \ldots, H$ ) corresponds to $H$ work durations. In the case of joint spouses' choices, participation and employment decisions are taken simultaneously by the two partners, and there will be $H^{2}$ combinations of spouses' labor supplies. 
The complex structure of the tax system implies that the disposable income is a function of total household income and household composition. Extensively, the disposable income of household $i$, for $i=1, \ldots, I$, can be computed as

$D^{i}= \begin{cases}w_{f}\left(h_{f}\right)+w_{m}\left(h_{m}\right)+y-T\left(w_{m}\left(h_{m}\right)\right)-T\left(w_{f}\left(h_{f}\right)\right)+F^{i}\left(w_{m}\left(h_{m}\right), w_{f}\left(h_{f}\right)\right) & \text { if } i \text { is a married couple, } \\ w_{j}(h)+y-T\left(w_{j}(h)\right)+F^{i}\left(0, w_{j}(h)\right) & \text { otherwise, }\end{cases}$

where $j=\{f, m\} . w_{f}$ and $w_{m}$ are the labor earnings of women and men, respectively; $y$ is net household non-labor income; $F^{i}\left(w_{m}, w_{f}\right)$ denotes transfers from the government; and $T(w)$ are taxes on gross earnings. In the rest of the section, the spousal gross wage $w_{m}\left(h_{m}\right)$ is taken as given if husband's labor supply is inelastic.

We assume that the household preferences are described by a linear stochastic utility function $U(\cdot)$ which depends on the alternative $h$, household disposable income $D(\cdot)$, and a set of exogenous socio-demographic characteristics $Z$ which account for observed heterogeneity across households. The utility is estimated separately for married and unmarried individuals:

$$
U^{i}= \begin{cases}\alpha_{\left(h_{f}, h_{m}\right)}+\beta_{\left(h_{f}, h_{m}\right)} D^{i}+\gamma_{\left(h_{f}, h_{m}\right)} Z^{i}+\epsilon_{\left(h_{f}, h_{m}\right)}^{i} & \text { if } i \text { is a married couple } \\ \alpha_{h}+\beta_{h} D^{i}+\gamma_{h} Z^{i}+\epsilon_{h}^{i} & \text { otherwise. }\end{cases}
$$

Notice that the effect of all variables included in $Z$ varies with $h^{17}$. In the case of inelastic husband's labor supply, the set of explanatory variables $Z$ contains controls for the labor market status of the husband. The difference $\left(\alpha_{h}-\alpha_{0}\right)+\left(\gamma_{h}-\gamma_{0}\right) Z^{i}$ captures the disutility of working (utility of leisure) an amount of time $h$. Finally, $\epsilon^{i}$ is a stochastic error component ${ }^{18}$.

We solve the problem by backward induction, starting from stage 2 . A household $i$ will maximize utility

$$
\begin{gathered}
V^{i}\left(w_{f}\left(h_{f}\right), w_{m}\left(h_{m}\right), y, Z\right)=\max _{\left\{h_{f}, h_{m}\right\}} U^{i}\left(h_{f}, h_{m}, D\left(w_{f}, w_{m}, y\right), Z\right) \text { if } i \text { is a married couple, } \\
V^{i}\left(w_{j}\left(h_{j}\right), y, Z\right)=\max _{\left\{h_{j}\right\}} U^{i}\left(h_{j}, D\left(w_{j}\left(h_{j}\right), y\right), Z\right) \quad \text { otherwise. }
\end{gathered}
$$

The expressions for $V^{i}\left(w_{f}\left(h_{f}\right), 0, y, Z\right)$ and $V^{i}\left(0, w_{m}\left(h_{m}\right), y, Z\right)$ are straightforward analogues of equation (8). In this stage, a household $i$ faces a trade-off between the utility from non working (enjoying leisure and carrying out domestic work) and working, augmenting the disposable income of the household.

In stage 1, members of household $i$ decide whether or not to enter the labor market. To make their choice, they compare the utility from not participating and the expected utility from entering the labor market. Let $c$ be the cost of entering the labor market and $E\left[V^{i}(\cdot)\right]$ be the expected utility generated by the maximization problem in stage 2 . Then, $\max \left\{U^{i}(0,0, D(0,0, y), Z), E\left[V^{i}\left(w_{f}\left(h_{f}\right), w_{m}\left(h_{m}\right), y, Z\right)\right]-c^{i}\left(h_{f}, h_{m}\right)\right\}$ if $i$ is a married couple,

$$
\max \left\{U^{i}(0, D(0, y), Z), E\left[V^{i}\left(w_{j}, y, Z\right)\right]-c^{i}\right\} \text { otherwise, }
$$

and two additional problems similar to (10) for $V^{i}\left(w_{f}\left(h_{f}\right), 0, y, Z\right)$ and $V^{i}\left(0, w_{m}\left(h_{m}\right), y, Z\right)$. 
We know that if $\epsilon$ is i.i.d. according to a type I extreme value distribution, the probability of observing an individual in the labor market, opting for a choice $h_{j}=k_{j}$ or a couple choosing $\left\{h_{f}=k_{f}, h_{m}=k_{m}\right\}$, is

$$
\begin{gathered}
\operatorname{Pr}\left(k_{f}, k_{m}\right)=\frac{e^{U^{i}\left(k_{f}, k_{m}, D\left(w_{f}\left(k_{f}\right), w_{m}\left(k_{f}\right), y\right), Z\right)}}{\sum_{h_{f}} \sum_{h_{m}} e^{U^{i}\left(h_{f}, h_{m}, D\left(w_{f}\left(h_{f}\right), w_{m}\left(h_{m}\right), y\right), Z\right)}}, \\
\operatorname{Pr}\left(k_{j}\right)=\frac{e^{U^{i}\left(k, D\left(w_{j}(k), y\right), Z\right)}}{\sum_{h \in H} e^{U^{i}\left(h, D\left(w_{j}(h), y\right), Z\right)}} \text { for j }=\mathrm{f}, \mathrm{m} .
\end{gathered}
$$

Moreover, $\operatorname{Pr}\left(k_{f}, 0\right)$ and $\operatorname{Pr}\left(0, k_{m}\right)$ can be computed in the same fashion as (12). Similarly, the probability of participating is

$$
\begin{gathered}
\operatorname{Pr}\left(s_{f}=1, s_{m}=1\right)=\frac{e^{E\left[V^{i}\left(w_{f}\left(h_{f}\right), w_{m}\left(h_{m}\right), y, Z\right)\right]-c^{i}\left(h_{f}, h_{m}\right)}}{e^{U U^{i}(0,0, D(0,0, y), Z)}+\sum_{f=\left\{0, w_{f}\left(h_{f}\right)\right\}} \sum_{m=\left\{0, w_{m}\left(h_{m}\right)\right\}} e^{E\left[V^{i}(f, m, y, Z)\right]-c^{i}(f, m)}} \\
\operatorname{Pr}\left(s_{j}=1\right)=\frac{e^{E\left[V^{i}\left(w_{j}, y, Z\right)\right]-c^{i}}}{e^{U^{i}(0, D(0, y), Z)}+e^{E\left[V^{i}\left(w_{j}, y, Z\right)\right]-c^{i}}} \text { for j=f,m, }
\end{gathered}
$$

where $s$ indicates the labor market status.

\subsection{The data and wage imputation}

We use micro data from the EU-SILC, the Community Statistics on Income and Living Conditions. The survey collects information relating to a broad range of issues in relation to income and living conditions. SILC is conducted by the Statistics Offices of the European countries involved in the project on an annual basis in order to monitor changes in income and living conditions over time.

Every person aged 16 years and over in a household is required to participate in the survey. Two different types of questions are asked in the household survey: household questions, and personal questions. The former covers details of accommodation and facilities together with regular household expenses (mortgage repayments, etc.). This information is supplied by the head of the household. The latter covers details on variables such as work, income, and health and are obtained from every household member aged 16 years and over. We combine household and personal information to construct a data set which contains information on the spouse of the interviewed household member.

We focus on the cross-sectional information of the years 2007-2011 ${ }^{19}$. We restrict the sample to women aged 26-54 years to avoid the modeling of schooling and retirement decisions. Moreover, we exclude self-employed men and women and individuals that are coded as disabled or unfitted to work. Descriptive statistics are in Table 13, Additional file 1: Appendix B.

The data set provides information on gross labor income of all members of the household $\left(w_{m}, w_{f}\right)$, and total household income. By difference, it is possible to compute the non-labor income $y$. Nevertheless, it is necessary to compute the potential income for all possible labor supply choices $h \in H$, including the non-employed. To correct for selection bias, a two-stage non-linear procedure is adopted which departs in few features from the standard Heckman correction. 
We consider a model in which individuals $i$ are sorted into 4 categories $0, \ldots, 3$ on the basis of an ordered-probit selection rule:

$$
\begin{aligned}
& z_{i}^{*}=\gamma^{\prime} t_{i}+u_{i} ; \\
& z_{i}= \begin{cases}0 \text { "out of the labor force" } & \text { if }-\infty<z_{i}^{*} \leq \mu_{1}, \\
1 \text { "unemployed" } & \text { if } \mu_{1}<z_{i}^{*} \leq \mu_{2}, \\
2 \text { "part-time employed" } & \text { if } \mu_{2}<z_{i}^{*} \leq \mu_{3}, \\
3 \text { "full-time employed" } & \text { if } \mu_{3}<z_{i}^{*}<\infty,\end{cases}
\end{aligned}
$$

where $\gamma$ is an unknown vector of parameters, $u_{i}$ is a standard normal shock, and the unknown cutoffs $\mu_{1}, \mu_{2}, \mu_{3}$ satisfy $\mu_{1}<\mu_{2}<\mu_{3}$. We assume that the independent variables $t_{i}$, vectors of demographic characteristics of agent $i$ and her spouse, and the categorial variable $z_{i}$ are observed, but the latent selection variable $z_{i}^{*}$ is unobserved.

We also consider an observed dependent variable $w_{i}$, the wage, that is a linear function of some observed demographic characteristics of agent $i$ and her spouse $x_{i}$, but the coefficients of $x_{i}$ depend on the category $z_{i}$ :

$$
w_{i}=\left\{\begin{array}{l}
\beta_{0}^{\prime} x_{i}+v_{i 0} \text { if } z_{i}=0, \\
\beta_{1}^{\prime} x_{i}+v_{i 1} \text { if } z_{i}=1, \\
\beta_{2}^{\prime} x_{i}+v_{i 2} \text { if } z_{i}=2, \\
\beta_{3}^{\prime} x_{i}+v_{i 3} \text { if } z_{i}=3,
\end{array}\right.
$$

where for each $j \in\{0,1,2,3\}$, $v_{i j}$ has a mean 0 , a variance $\sigma_{j}^{2}$, and is bivariate normal with $u_{i}$, with correlation $\rho_{j}$. We assume that the shocks $v_{i j}$ and $u_{i}$ are independently and identically distributed across observations. Our goal is to estimate the parameter vectors $\beta_{0}, \ldots, \beta_{3} . w_{i}$ could also be missing for certain categories $j$, in which case $\beta_{j}, \rho_{j}$, and $\sigma_{j}$ do not exist.

Since only one category $j$ is observed for each individual and the observations are independent, the correlations between $v_{i j}$ and $v_{i k}$ for $j \neq k$ cannot be identified, so we do not model or estimate them.

We proceed with a two-step estimation procedure that is a generalization of Heckman's (1979) estimator for the binary case. In the first step, we estimate (16) by an ordered probit of $z$ on $t$, yielding the consistent estimates $\hat{\gamma}, \hat{\mu}_{1}, \hat{\mu}_{2}, \hat{\mu}_{3}$. Define $\hat{z}_{i}^{*} \equiv t_{i} \hat{\gamma}$ and $\lambda_{i} \equiv$ $E\left[u_{i} \mid z_{i}, t_{i}\right]$. Then, a consistent estimator of $\lambda_{i}$ is

$$
\hat{\lambda}_{i} \equiv \frac{\phi\left(\hat{\mu}_{j}-\hat{z}_{i}^{*}\right)-\phi\left(\hat{\mu}_{j+1}-\hat{z}_{i}^{*}\right)}{\Phi\left(\hat{\mu}_{j+1}-\hat{z}_{i}^{*}\right)-\Phi\left(\hat{\mu}_{j}-\hat{z}_{i}^{*}\right)},
$$

where $j=z_{i}$. Using $E\left[w_{i} \mid z_{i}, t_{i}, x_{i}\right]=\beta_{j}^{\prime} x_{i}+\rho_{j} \sigma_{j} \lambda_{i}$, we can consistently estimate $\beta_{j}$ with OLS regressions of $w$ on $x$ and $\hat{\lambda}$ by using only the observations $i$ for which $z_{i}=j^{20}$.

\subsection{Estimation results}

To assess the properties of the model, we first examine its ability to reproduce the basic features of labor force participation and employment observed in our sample by comparing model simulations to observed data.

Table 4 and Table 16 in Additional file 1: Appendix $C$ summarize the results of the estimations of the labor force participation and employment rates (part-time and fulltime). The models replicate the percentage of men and women in the labor force and the percentage of those who are employed (in part-time and full-time jobs) for both gender and marital status. 
Table 4 Estimation results (\%)

\begin{tabular}{|c|c|c|c|c|c|c|c|c|c|c|}
\hline \multirow[b]{2}{*}{$\begin{array}{l}\text { Taxation } \\
\text { System }\end{array}$} & \multicolumn{2}{|c|}{ Total } & \multirow[t]{2}{*}{ Unmarried women } & \multirow[t]{2}{*}{ Unmarried men } & \multicolumn{2}{|c|}{ Married women } & \multicolumn{2}{|c|}{ Married men } & \multicolumn{2}{|c|}{$\begin{array}{c}\text { Married women } \\
\text { Inelastic husband's labor supply }\end{array}$} \\
\hline & Women & Men & & & $\begin{array}{c}\text { With } \\
\text { children }\end{array}$ & $\begin{array}{l}\text { Without } \\
\text { children }\end{array}$ & $\begin{array}{c}\text { With } \\
\text { children }\end{array}$ & $\begin{array}{l}\text { Without } \\
\text { children }\end{array}$ & $\begin{array}{l}\text { With } \\
\text { children }\end{array}$ & $\begin{array}{l}\text { Without } \\
\text { children }\end{array}$ \\
\hline \multicolumn{11}{|c|}{ Average Tax Rate of Households } \\
\hline Benchmark Model & \multicolumn{2}{|c|}{24.13} & 22.05 & 24.52 & 23.46 & 28.03 & & & 20.24 & 27.38 \\
\hline \multicolumn{11}{|c|}{ Second Earner Tax Rate } \\
\hline Benchmark Model & 25.26 & 29.47 & 22.05 & 24.52 & 26.75 & 27.21 & 35.33 & 31.57 & 21.18 & 25.97 \\
\hline \multicolumn{11}{|l|}{ Participation Rate } \\
\hline Data & 64.18 & 81.72 & 80.94 & 81.71 & 58.06 & 60.97 & 81.97 & 81.00 & 58.06 & 60.97 \\
\hline Benchmark Model & 64.42 & 82.09 & 81.98 & 82.35 & 58.10 & 61.16 & 82.02 & 81.25 & 58.11 & 61.18 \\
\hline \multicolumn{11}{|c|}{ Employment Rate: Part-time } \\
\hline Data & 14.62 & 3.33 & 11.45 & 4.52 & 16.99 & 11.28 & 1.98 & 2.70 & 16.99 & 11.28 \\
\hline Benchmark Model & 14.62 & 3.33 & 11.45 & 4.52 & 16.99 & 11.28 & 1.98 & 2.70 & 16.99 & 11.28 \\
\hline \multicolumn{11}{|c|}{ Employment Rate: Full-time } \\
\hline Data & 43.71 & 72.84 & 59.40 & 68.35 & 36.62 & 45.12 & 77.95 & 75.30 & 36.62 & 45.12 \\
\hline Benchmark Model & 43.71 & 72.84 & 59.40 & 68.35 & 36.62 & 45.12 & 77.95 & 75.30 & 36.62 & 45.12 \\
\hline
\end{tabular}


Figure 4 plots the realized and predicted labor force participation rates of married women by percentile of husbands' incomes. The model with inelastic husband's labor supply slightly underestimates the participation rates of women married to husbands in the lowest percentile and overestimates the participation of higher income wives. The model with joint decisions delivers a more precise match.

A similar trend for married women is confirmed in panel (a) of Figure 5, where the realized and predicted participation rates are plotted against the household's disposable income. In panel (b) of the same figure, we plot the participation rates of husbands, showing that it is inelastic to the household's disposable income. Interestingly, a similar trend is obtained if participation rates are plotted against wife's income (red lines).

As a final validation exercise, we plot the estimated participation rates by age and marital status in Figure 6. We can observe that both models generate the levels and the decreasing trend of the participation rate of the different subgroups of women. Even though the taxation system is not age-dependent, the age of women is correlated with their own potential earnings, their husband's earnings, and the number of children. As we described above, all of these elements affect the tax burden, and hence, the labor decision of second earners ${ }^{21}$.

\subsection{Uncompensated labor supply elasticities}

The parameter estimates of our models do not directly reveal the sensitivity of labor supply to financial incentives. Hence, in this section, we provide labor supply elasticities for several subgroups of the sample. Uncompensated elasticities for both spouses' wage rates are relevant to analyze because they are the main driving force behind the tax policy effects.

The elasticities are derived by predicting labor supply for each individual when the gross wages are increased by 1 percent. The estimates are based on 100 sets of simulations, where the coefficients of the preferences are kept fixed to those estimated

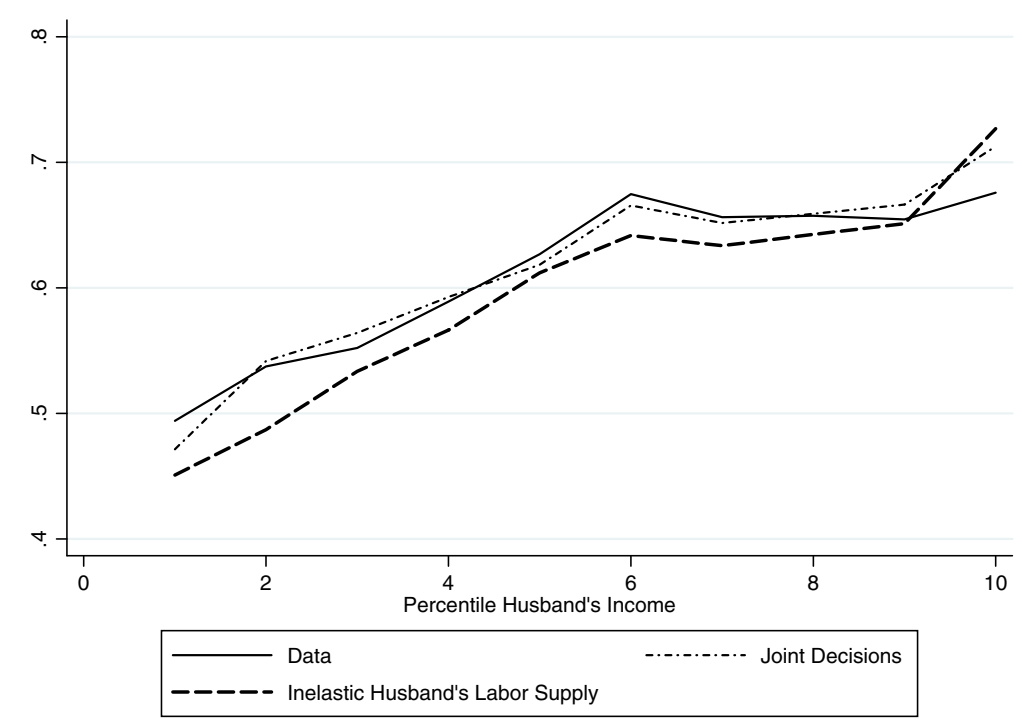

Figure 4 Labor force participation - data vs models. Source: authors' computations from EU-SILC data (2007-2011) 


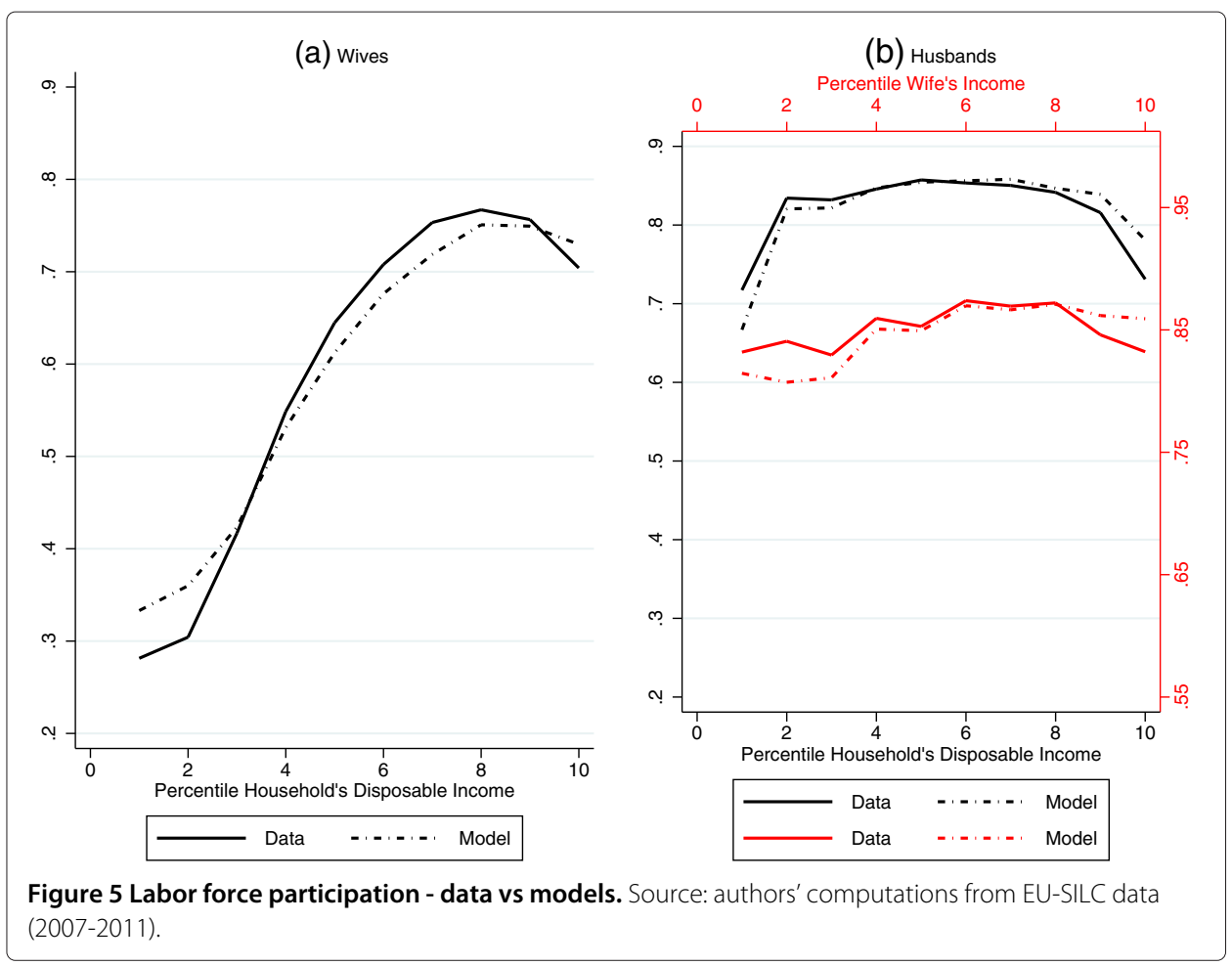

before the increase in the wages. Individual responses are averaged across individuals to yield aggregate labor supply elasticities. Note that the elasticities depend on preferences, demographic and educational structure, and tax functions. The results are in Table 5.

The own wage elasticity of married men is numerically smaller than the wage elasticities of married women, in accordance with the findings in labor supply studies. In the

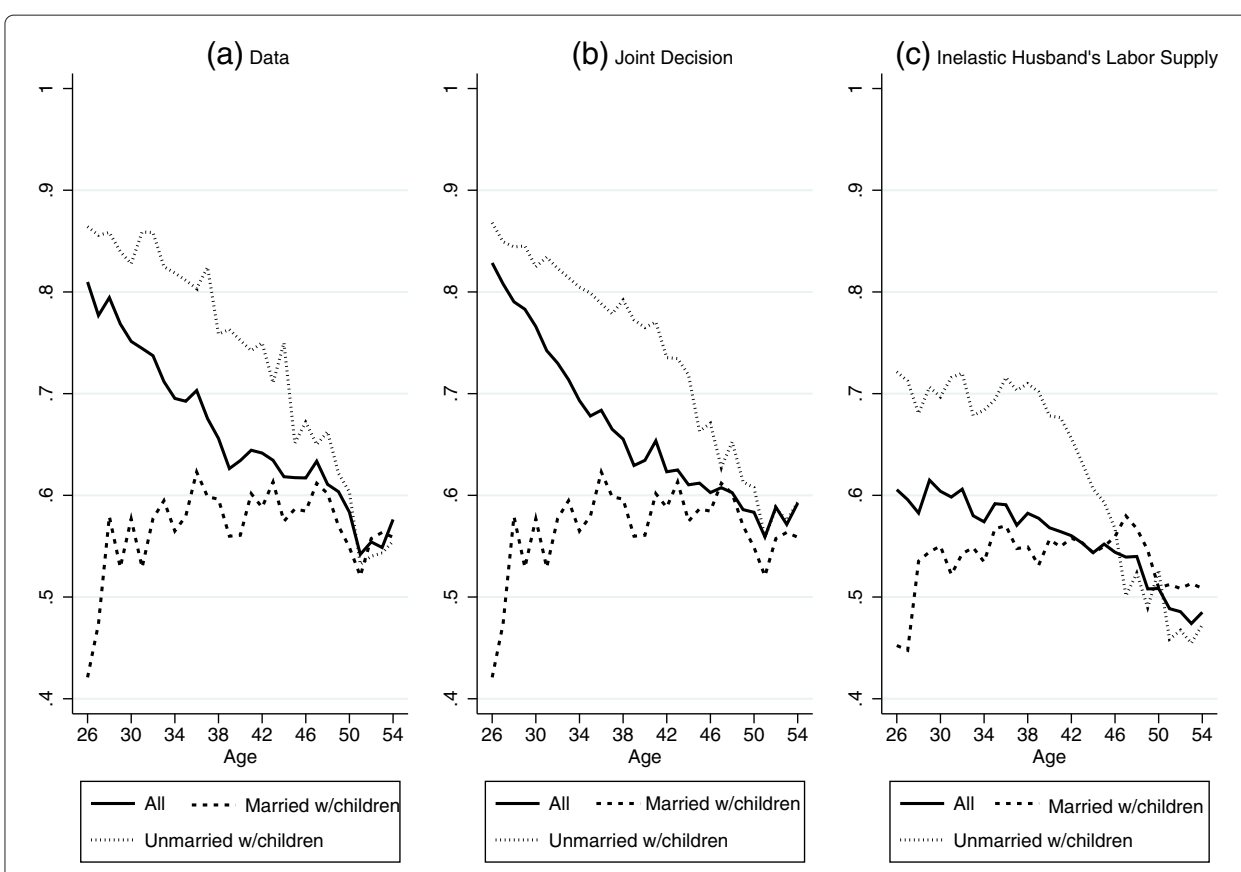

Figure 6 LFP and employment rates of italian women by age - data vs model. Source: authors' computations from EU-SILC data (2007-2011). 
Table 5 Uncompensated labor supply elasticities

\begin{tabular}{|c|c|c|c|c|c|c|c|c|}
\hline & \multicolumn{3}{|c|}{ Male elasticities } & \multicolumn{5}{|c|}{ Female elasticities } \\
\hline & \multirow{3}{*}{$\begin{array}{c}\text { Single } \\
\text { Own wage }\end{array}$} & \multirow{2}{*}{\multicolumn{2}{|c|}{ Married }} & \multirow{3}{*}{$\begin{array}{c}\text { Single } \\
\text { Own-wage }\end{array}$} & \multicolumn{4}{|c|}{ Married } \\
\hline & & & & & \multicolumn{2}{|c|}{ Joint decisions } & \multicolumn{2}{|c|}{$\begin{array}{l}\text { Inelastic husband's } \\
\text { Labor supply }\end{array}$} \\
\hline & & Own wage & Cross wage & & Own wage & Cross wage & Own wage & Cross wage \\
\hline All & 0.683 & 0.585 & 0.134 & 0.363 & 1.015 & -0.055 & 0.741 & 0.824 \\
\hline $10 \%$ poorest & 0.767 & 0.732 & 0.080 & 0.322 & 0.801 & -0.056 & 0.613 & 0.205 \\
\hline $80 \%$ in the middle & 0.651 & 0.523 & 0.135 & 0.365 & 1.049 & -0.059 & 0.748 & 0.866 \\
\hline $10 \%$ richest & 0.844 & 0.453 & 0.185 & 0.387 & 0.950 & -0.027 & 0.827 & 1.165 \\
\hline North-East & 0.482 & 0.529 & 0.156 & 0.307 & 1.093 & -0.046 & 0.534 & 0.637 \\
\hline North-West & 0.532 & 0.596 & 0.140 & 0.272 & 1.040 & -0.083 & 0.757 & 0.911 \\
\hline Center & 0.804 & 0.475 & 0.129 & 0.400 & 1.067 & -0.028 & 0.897 & 1.037 \\
\hline South & 0.846 & 0.742 & 0.120 & 0.425 & 0.950 & -0.061 & 0.771 & 0.773 \\
\hline Islands & 0.827 & 0.576 & 0.113 & 0.458 & 0.789 & -0.074 & 0.700 & 0.666 \\
\hline w/o children & 0.682 & 0.344 & 0.160 & 0.410 & 0.922 & -0.071 & 0.678 & 0.694 \\
\hline with children & 0.768 & 0.658 & 0.126 & -0.238 & 1.043 & -0.051 & 0.760 & 0.863 \\
\hline
\end{tabular}


rest of the table, we illustrate the variation of the labor supply elasticities with disposable household income, geographical area of residence, and presence of children.

The own wage elasticities of married men are decreasing with household disposable income, while the opposite is true for married women (in both models). This is in line with the system of negative incentives provided to wives living in low-income households.

The cross wage elasticity of married women (in the joint decision model) is negative and increasing in household disposable income. By contrast, the cross wage elasticity of married men is positive and increasing in household disposable income. It is estimated to be 0.134 , on average, for men (about a fourth of the corresponding own wage elasticity) and -0.055 for women. This means that a 10 percent increase in spousal wage causes a 1.34 percent increase in husband's participation rate and a 0.55 percent decrease in wife's participation rate. Hence, changes in wage differences in the family may lead to within-household divergence in participation.

An important feature distinguishes the joint decision model from the model with inelastic husband's labor supply: In the latter, the cross wage elasticity of wives is positive for all levels of household income. This suggests that assuming a perfectly inelastic labor supply of husbands may deliver an inaccurate analysis of spousal responses to wage increases.

Single women have an own wage elasticity which is lower than the elasticity of men. In general, unmarried agents have an elasticity which is increasing with household's disposable income.

Geographically, own wage elasticity is increasing from north to south for all but married women. The opposite is true for the cross wage elasticity, which numerically decreases for both husbands and wives. Lastly, households with children are more sensitive to changes in own wages, regardless of the marital status.

\section{Alternative taxation systems}

The reform of the taxation system has been a topic of several discussions in the Italian government. In this section, we use the parameters obtained from the estimation of the models to simulate the labor force participation rate and the employment rate under three different taxation systems that have been considered in the political and academic debate. These are joint taxation, the working tax credit, and gender-based taxation. In Table 15, Additional file 1: Appendix C, we summarize the main characteristics of these alternative systems. As the tax reform simulations are performed in a partial equilibrium setting, the offered wages are considered as exogenously given, and they are unaffected by a change of tax systems.

An important issue involved in our tax simulation exercises is that when different tax units and tax systems are considered, the total tax revenue might change. We analyze what happens to the amount of tax paid by a household in the case of constant total tax revenue, which is achieved by increasing each household's tax by a constant amount ${ }^{22}$. The results of the simulations are summarized in Table 16, Additional file 1: Appendix C.

\subsection{Three simulated reforms}

Let us summarize the main characteristics of the three alternative taxation systems.

Joint family taxation: It is currently implemented in Portugal, France and Germany. It provides tax advantages to large families with low-incomes as the average tax rate 
decreases with the number of household components. As shown by some existing literature, this system creates a system of negative incentives to participation for both of the spouses, and especially for women ${ }^{23}$.

We simulate a taxation system similar to the one we find in France, where the gross income is the household income divided by the number of parts (the quotient familial, a coefficients which increases with the number of household components). Let $w_{m}$ and $w_{f}$ be the gross yearly incomes of the two spouses, $q$ be quotient familial, and $T(\cdot)$ be the tax schedule. Then, the amount of tax is equal to $q T\left(\left(w_{m}+w_{f}\right) / q\right)$ instead of $T\left(w_{m}\right)+T\left(w_{f}\right)$. In the simulation, we drop all tax credits for dependent spouses and universal cash transfers. The quotient familial is assumed to equal the number of household components.

Working tax credit: The American Earned Income Tax Credit (EITC) and the British Working Tax Credit (WTC) are two systems of negative taxation. The tax unit is the individual. Based on these systems, households where both of the spouses are employed have the right to receive a tax credit which is increasing with the size of the family and which can even become a transfer ${ }^{24}$. Chote et al. (2007) provide evidence of an increase from 45 to 55 percent in employment rates of unmarried mothers in Great Britain. Eissa and Liebman (1996) and Ellwood (2000) obtain similar results for the EITC.

We assume that individual working tax credits amount to 1,840 euros, regardless of the individual or household income. Moreover, we eliminate the tax credits for dependent spouses, and we set the universal cash transfers to 137 euros a month for the first child and 121 euros a month for the following children, regardless of the total household income $^{25}$. This proposition is in line with the tax system of several European countries, and with the suggestions of Atkinson (2011) and Levy et al. (2007).

Gender-based taxation: Alesina et al. (2011) suggest a gender-based taxation system which implies a lower tax schedule for individuals characterized by a participation rate elastic to income. In other words, they propose a lower tax rate for women than for men, regardless of the marital status. They show that this results in a higher participation rate of women. Moreover, the increase in wives' bargaining power, due to an increase in their net disposable income, affects the division of labor inside the household in their favor. Nevertheless, the gender-based taxation favors high income women and penalizes lowincome men. Furthermore, it would imply an equal treatment of two single parent families identical in income but different in the gender of the parents. Saint-Paul (2007) underlines that there is no reason to believe that the participation rate of women is always more elastic than that of men. For example, single women, with and without children, do not behave differently than men. Alternatively, Saint-Paul (2007) suggests to apply a lower tax rate to supplemental hours worked, regardless of the gender.

In the simulation, we apply the same tax rates for men and women, but women only pay 67 percent of their total tax net of standard tax credits, as suggested by Alesina et al. (2011).

\subsection{Results of the simulated reforms}

In Table 6, we show the results of the simulated reforms as differences from the benchmark model ${ }^{26}$. 
Table 6 Alternative (revenue neutral) taxation systems: differences from the benchmark model

\begin{tabular}{|c|c|c|c|c|c|c|c|c|c|c|}
\hline \multirow[b]{2}{*}{$\begin{array}{l}\text { Taxation } \\
\text { System }\end{array}$} & \multicolumn{2}{|c|}{ Total } & \multirow[t]{2}{*}{ Unmarried women } & \multirow[t]{2}{*}{ Unmarried men } & \multicolumn{2}{|c|}{ Married women } & \multicolumn{2}{|c|}{ Married men } & \multicolumn{2}{|c|}{$\begin{array}{c}\text { Married women } \\
\text { Inelastic husband's labor supply }\end{array}$} \\
\hline & Women & Men & & & $\begin{array}{c}\text { With } \\
\text { children }\end{array}$ & $\begin{array}{l}\text { Without } \\
\text { children }\end{array}$ & $\begin{array}{l}\text { With } \\
\text { children }\end{array}$ & $\begin{array}{l}\text { Without } \\
\text { children }\end{array}$ & $\begin{array}{l}\text { With } \\
\text { children }\end{array}$ & $\begin{array}{l}\text { Without } \\
\text { children }\end{array}$ \\
\hline \multicolumn{11}{|l|}{ Participation Rate } \\
\hline Joint Tax & -0.48 & -0.94 & -0.69 & +0.10 & -0.58 & +0.14 & -2.71 & +0.44 & -3.58 & +0.51 \\
\hline Working Tax Credit & +1.61 & -1.53 & -1.51 & -2.79 & +3.06 & +1.11 & +0.06 & -1.39 & +0.56 & +0.06 \\
\hline Gender-Based Tax & +0.89 & -4.0 & +2.15 & -0.83 & -0.30 & +4.65 & -9.97 & +2.64 & +0.32 & +4.0 \\
\hline \multicolumn{11}{|c|}{ Employment Rate: Part-time } \\
\hline Joint Tax & -4.27 & -0.03 & -1.90 & -0.28 & -5.36 & -2.74 & +0.37 & +0.26 & -1.87 & -0.51 \\
\hline Working Tax Credit & +2.63 & +0.92 & -0.48 & -0.07 & +1.87 & +1.46 & +2.38 & +0.38 & +0.60 & +0.55 \\
\hline Gender-Based Tax & -3.82 & +0.36 & -1.06 & +0.11 & -5.02 & -2.02 & +0.50 & +1.63 & -1.52 & -0.51 \\
\hline \multicolumn{11}{|c|}{ Employment Rate: Full-time } \\
\hline Joint Tax & +5.84 & -1.21 & -0.92 & -0.13 & +2.72 & +1.70 & -2.55 & -1.28 & +0.25 & +0.77 \\
\hline Working Tax Credit & -2.40 & -2.48 & -2.72 & -2.92 & -1.43 & -1.91 & -2.15 & -1.73 & +0.05 & -0.18 \\
\hline Gender-Based Tax & +7.38 & -4.17 & +2.53 & -1.0 & +0.96 & +3.44 & -9.24 & -1.25 & +1.68 & +2.10 \\
\hline
\end{tabular}

Source: Authors' computations from EU-SILC data (2007-2011). 
In the joint family taxation scenario, participation rates do not show important changes if husbands and wives decide jointly whether or not to work. On the contrary, labor force participation of married mothers falls by more than 3 percent if the husbands' labor supply is inelastic. In Figure 7, which shows the participation rates by level of education, we can see that when the labor supply of husbands is exogenously given, low educated mothers leave the labor market at a higher rate than those with college degrees. Employment rates drop for unmarried individuals, while married women exit part-time to enter full-time employment ${ }^{27}$. As shown in Figure 8, Additional file 1: Appendix D, the SET of married women increases in husband's income (panels b) and d)) exhibits higher values than the benchmark model (panels a) and c)), implying a decreasing labor force participation in husband's income. The reason is that without tax credits and universal cash transfers, the SET is now equal to $q\left[T\left(\left(w_{m}+w_{f}\right) / q\right)-\right.$ $\left.T\left(w_{m} / q\right)\right] / w_{f}$, which is positive for every $w_{m} \geq w_{f}$ and increasing in the difference $\left(w_{m}-w_{f}\right)$.

But then what are the reasons for the high (and inelastic) labor force participation rate of French women? Despite the disincentives created by the quotient familial, the French government provides a wide range of allowances, tax deductions, and reductions in social security contributions to families with children. For example, an allowance of 50 percent up to a maximum of 2,300 euros per child under seven years of age is granted towards the costs of childcare outside of the home. Moreover, a tax allowance of 50 percent is credited against the costs of assistance with domestic duties, which include childcare. To these fiscal measures, we should add the widespread system of day-care centers (individual and collective) for children both younger and older than three years of age,; monetary transfers to parents who decide to exit the labor market to take care of the children,; and a system of primary schools that offers overtime assistance to children with parents at work ${ }^{28}$.

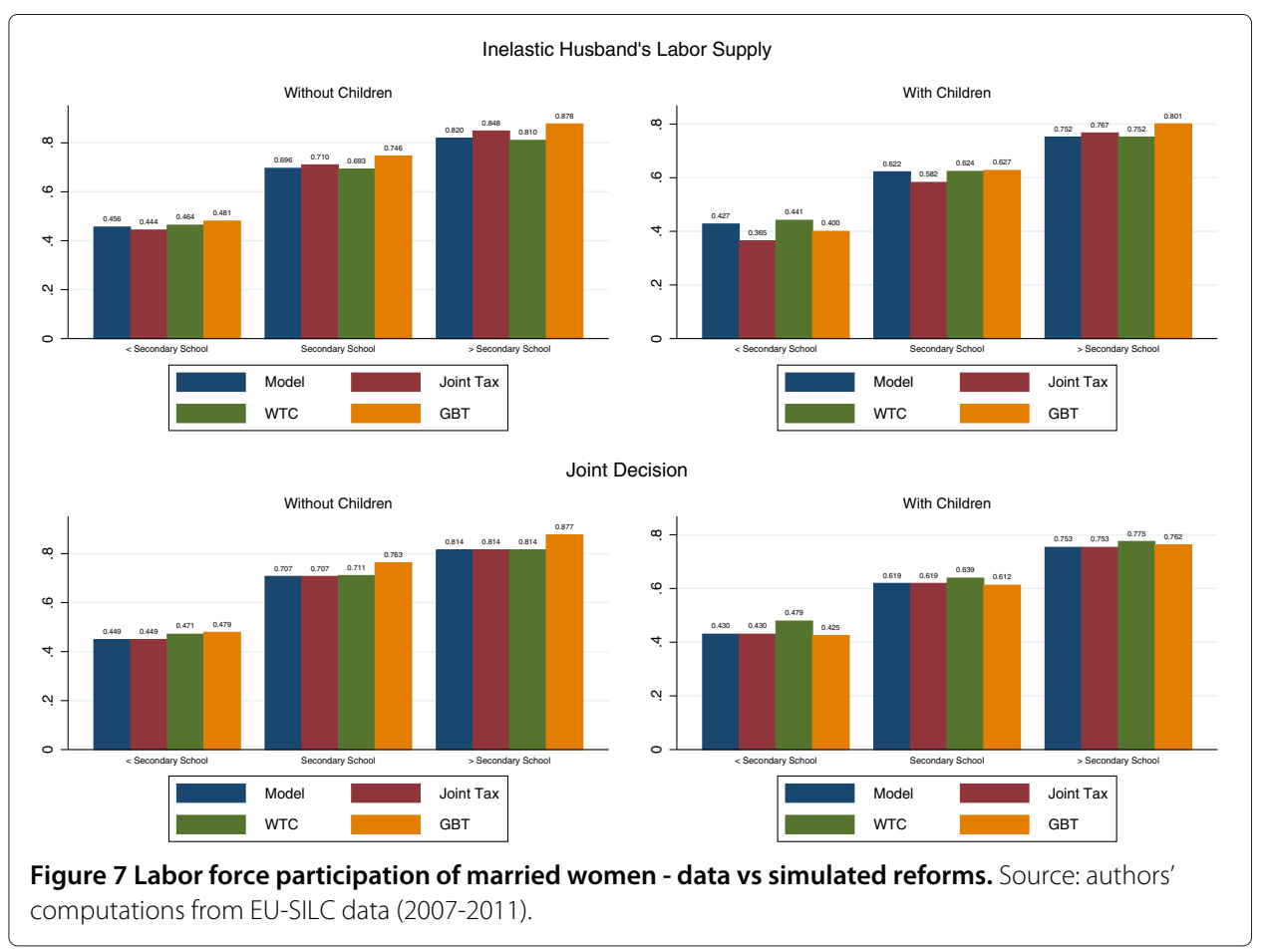


This set of services (other than fiscal) provide incentives to low-income French mothers to enter (or to remain) into labor force participation. In Italy, the disincentives created by the fiscal system are not offset by any other family policy aimed to reduce the burden of the child care cost.

The Working Tax Credit provides incentives to married women who increase their participation rate up to 3 percentage points. Contrary to the Italian system, the working tax credit has all of the characteristics of an individual taxation system. In fact, tax credits or transfers (and hence, second earner tax rates) do not depend on the spouse's income and hence do not vary with the marital status. This is shown in Figure 9, Additional file 1: Appendix D, panels b) and d), where the SET is constant at about 20 percent for married women. Similarly, panels a) and c) show that the SET changes only with women's income. Another interesting feature of this system is that it provides incentives to undertake low earnings jobs. As we can see in Figure 9 (panels a) and c)), the SET is particularly low (and even negative) at low levels of earnings. This prediction can also be seen from Figure 7, bottom panel, where the raise in labor supply mostly comes from low educated mothers. The model forecasts a raise in part-time employment rates of married men and women of about 2 percentage points. Unmarried individuals do not benefit from the simulated tax system.

Finally, the lower taxation of the Gender-Based system boosts the participation and the full-time employment rate of all women, especially if they have children. In particular, it increases participation by about 1 percent and the full-time employment rate by about 7 percentage points. From Figure 10, Additional file 1: Appendix D, we can see that this system leads to a decrease in the SET of every woman, even though it maintains a relatively high SET of low-income married women (as we did not change the system of tax credits and universal cash transfers). However, the tax credits for dependent spouses and cash transfers continue to generate the positive correlation between labor force participation and husband's income.

Tables 17, 18 and 19 in Additional file 1: Appendix C show the transition flows by education level, number of children, and household disposable income of married women with endogenous husband's participation decision.

\section{Welfare implications}

Table 7 reports the Gini coefficients of disposable household income. We find that inequality in distribution of disposable income decreases for married couples, in both models, in all of the simulated tax systems but the gender-based taxation if they do not have children. If there are children in the household, and husband's labor supply is exogenous, the other reform that decreases inequality is the working tax credit. The highest increase is experienced by unmarried men and women with children.

In order to evaluate the welfare effects of the estimated and simulated tax systems, we compute several measures of poverty. In general, the tax system has a pervasive impact on poverty, both directly through its role in the distribution of society's resources and indirectly through its effects on the incentives for economic decisions like working and saving. We decide to focus on poverty measures as we think that the impact of tax reform on low-income families is especially important in light of the persistence of poverty, wage stagnation at the bottom, and the growth of income inequality. Our choice is also motivated by the last report of the National Institute of Statistics of Italy (Istat (2012)), which 
Table 7 Gini coefficients

\begin{tabular}{|c|c|c|c|c|c|c|c|c|}
\hline & \multicolumn{2}{|c|}{ Unmarried men } & \multicolumn{2}{|c|}{ Unmarried women } & \multicolumn{2}{|c|}{$\begin{array}{l}\text { Married couples } \\
\text { Joint decision }\end{array}$} & \multicolumn{2}{|c|}{$\begin{array}{c}\text { Married couples } \\
\text { Inelastic husband's } \\
\text { labor supply }\end{array}$} \\
\hline & 0 children & 1 or more children & $\mathbf{0}$ children & 1 or more children & 0 children & 1 or more children & 0 children & 1 or more children \\
\hline Benchmark & 35.75 & 40.87 & 39.56 & 39.51 & 32.33 & 31.36 & 38.65 & 38.99 \\
\hline Joint taxation & 36.94 & 60.55 & 42.31 & 59.53 & 34.19 & 37.05 & 39.84 & 43.30 \\
\hline Working tax-credit & 38.11 & 44.48 & 43.25 & 43.26 & 33.60 & 31.55 & 38.07 & 37.60 \\
\hline Gender based tax & 35.61 & 33.51 & 36.00 & 36.02 & 27.24 & 34.15 & 31.22 & 35.33 \\
\hline
\end{tabular}


documents an increase in the poverty incidence among the households with a worker as the reference person ${ }^{29}$.

In our computations, we define $y_{i}(j)$ as the equivalised disposable income of individual $i$ in household $j$, that is, the total income of a household after tax and other deductions which is available for spending or saving, divided by the number of household members converted into equalised adults ${ }^{30}$. The poverty measures are defined as follows:

(1) Head count index: it measures the proportion of the population for whom income is below the poverty line ${ }^{31}$. Let $s(j)$ be the number of members of household $j$ and $P$ be the poverty line. Then, the head count index is defined as

$$
H C=\sum_{i} H C_{i}=\sum_{i}\left(\frac{\mathbf{1}_{P}\left(y_{i}^{j}\right) * s(j)}{\sum_{j} s(j)}\right)
$$

where

$$
\mathbf{1}_{P}\left(y_{i}(j)\right)=\left\{\begin{array}{l}
1 \text { if } y_{i}(j) \leq P \\
0 \text { otherwise }
\end{array}\right.
$$

The head count index has the disadvantage of ignoring the differences in well-being between different poor individuals.

(2) Poverty gap: it is the average, over all individuals, of the gaps between the income of individuals that are below the poverty line. The poverty gap is

$$
P G=\sum_{i} P G_{i}=\sum_{i}\left[H C_{i} *\left(P-y_{i}(j)\right)\right]
$$

(3) Aggregate poverty gap: it measures the average transfer (in euros) to poor households that is necessary to reach the poverty line.

$$
A P G=\sum_{i}\left[\frac{s(j) * \max \left[\left(P-y_{i}(j)\right), 0\right]}{1,000}\right]
$$

The results are in Table 8 .

In all of the simulations, the joint decision model provides lower poverty measures than the model with inelastic husband's labor force participation. Of all the tax systems, the gender-based system stands out for the lowest poverty measures for any household composition. The benchmark model and the joint taxation system predict lower poverty measures for childless couples or households with one child than the tax credit system. The tax credit decreases the percentage of married couples with two children at risk of poverty.

\section{Conclusions}

In this paper, we have used micro data from EU-SILC to estimate two structural models of labor supply: one with inelastic husband's labor supply and one with joint couple decisions. In both models, non-labor income is given, and agents decide, in two stages, whether to search for a job and whether to accept it or not.

We show that the models match the low level of the Italian labor force participation and employment rates and replicates the positive correlation between wife's participation rate and husband's yearly income. Moreover, we show that the Italian individual taxation 
Table 8 Poverty measures

\begin{tabular}{|c|c|c|c|c|}
\hline & & $\begin{array}{l}\text { Head count } \\
\text { index (\%) } \\
(1)\end{array}$ & $\begin{array}{c}\text { Poverty } \\
\text { gap } \\
\text { (2) }\end{array}$ & $\begin{array}{c}\text { Aggregate } \\
\text { poverty gap } \\
\text { (3) }\end{array}$ \\
\hline & & & Benchmark Model & \\
\hline & 0 children & 13.90 & 137.69 & 13439.31 \\
\hline \multirow[t]{3}{*}{ Married (Joint decision) } & 1 child & 12.81 & 168.79 & 17874.27 \\
\hline & 2 children & 12.02 & 194.08 & 21906.01 \\
\hline & 0 children & 16.71 & 163.04 & 16615.21 \\
\hline \multirow[t]{3}{*}{ Married (Inelastic husband's LFP) } & 1 child & 15.73 & 205.91 & 22153.21 \\
\hline & 2 children & 15.54 & 248.64 & 27208.92 \\
\hline & 0 children & 28.75 & 170.91 & 11712.83 \\
\hline \multirow[t]{3}{*}{ Unmarried Men } & 1 child & 34.74 & 344.25 & 19521.33 \\
\hline & 2 children & 18.60 & 245.18 & 25963.36 \\
\hline & 0 children & 32.51 & 193.28 & 11712.83 \\
\hline \multirow[t]{4}{*}{ Unmarried Women } & 1 child & 32.07 & 317.76 & 19521.33 \\
\hline & 2 children & 53.33 & 702.86 & 25963.36 \\
\hline & & & Joint Tax & \\
\hline & 0 children & 15.64 & 155.00 & 17927.00 \\
\hline \multirow[t]{3}{*}{ Married (Joint decision) } & 1 child & 18.92 & 249.34 & 23842.90 \\
\hline & 2 children & 15.71 & 253.75 & 29220.93 \\
\hline & 0 children & 16.64 & 161.89 & 18337.78 \\
\hline \multirow[t]{3}{*}{ Married (Inelastic husband's LFP) } & 1 child & 17.27 & 224.64 & 24486.23 \\
\hline & 2 children & 18.29 & 290.10 & 30111.85 \\
\hline & 0 children & 29.97 & 172.24 & 12420.33 \\
\hline \multirow{3}{*}{ Unmarried Men } & 1 child & 54.93 & 544.29 & 20700.47 \\
\hline & 2 children & 23.26 & 306.48 & 27531.62 \\
\hline & 0 children & 34.85 & 207.23 & 12420.33 \\
\hline \multirow[t]{4}{*}{ Unmarried Women } & 1 child & 52.69 & 522.15 & 20700.47 \\
\hline & 2 children & 72.38 & 953.89 & 27531.62 \\
\hline & & & Working Tax Credit & \\
\hline & 0 children & 16.07 & 159.225 & 14769.07 \\
\hline \multirow[t]{3}{*}{ Married (Joint decision) } & 1 child & 17.73 & 233.61 & 19642.85 \\
\hline & 2 children & 9.95 & 160.68 & 24073.51 \\
\hline & 0 children & 16.54 & 163.91 & 16638.86 \\
\hline \multirow[t]{3}{*}{ Married (Inelastic husband's LFP) } & 1 child & 15.65 & 206.30 & 22129.67 \\
\hline & 2 children & 15.31 & 247.21 & 27121.26 \\
\hline & 0 children & 31.47 & 187.08 & 12832.33 \\
\hline \multirow[t]{3}{*}{ Unmarried Men } & 1 child & 37.87 & 375.26 & 21387.15 \\
\hline & 2 children & 18.60 & 245.18 & 28444.91 \\
\hline & 0 children & 35.66 & 212.00 & 12832.33 \\
\hline \multirow[t]{4}{*}{ Unmarried Women } & 1 child & 35.81 & 354.82 & 21387.15 \\
\hline & 2 children & 49.52 & 652.66 & 28444.91 \\
\hline & & & Gender-Based Tax & \\
\hline & 0 children & 2.22 & 28.13 & 3146.27 \\
\hline \multirow[t]{3}{*}{ Married (Joint decision) } & 1 child & 1.92 & 31.12 & 3838.30 \\
\hline & 2 children & 2.18 & 45.87 & 4534.91 \\
\hline & 0 children & 2.85 & 37.72 & 8581.80 \\
\hline \multirow[t]{3}{*}{ Married (Inelastic husband's LFP) } & 1 child & 5.37 & 82.08 & 10813.72 \\
\hline & 2 children & 9.87 & 165.28 & 13015.35 \\
\hline & 0 children & 1.37 & 18.97 & 1092.37 \\
\hline \multirow[t]{3}{*}{ Unmarried Men } & 1 child & 4.07 & 61.34 & 1458.27 \\
\hline & 2 children & 4.65 & 61.30 & 1786.77 \\
\hline & 0 children & 0.99 & 11.37 & 1092.37 \\
\hline \multirow[t]{2}{*}{ Unmarried Women } & 1 child & 4.89 & 51.89 & 1458.27 \\
\hline & 2 children & 7.62 & 100.41 & 1786.77 \\
\hline
\end{tabular}

Source: Authors' computations from EU-SILC data (2007-2011). 
system generates disincentives for women's labor supply, especially when married with children. This is due to a set of tax credits for dependent spouses and children, universal cash transfers for children that increase the fiscal burden of low-income households, and the second earner tax rate of women married to low-income or unemployed men.

We then use the estimated parameters to measure the behavioral effects of alternative tax systems: joint family taxation, a system inspired by the British working tax credit, and gender-based taxation. We show that the first implies a substantial drop in the participation rate of married women. The working tax credit and the gender-based tax systems boost the participation rate, with the effects of the former being concentrated on unskilled and low educated women.

Overall, the results of the simulations show that moving towards a system of tax credits in line with the British or the American ones would reduce the fiscal burden of low earnings workers, mostly married women. Cash transfers that are independent of the total household income would reduce the disincentives to work created by the Italian taxation system. We could also expect that providing incentives to take up low-income jobs would decrease the incentives of taking up irregular jobs.

\section{Endnotes}

${ }^{1}$ The second earner tax is the amount of tax paid on an additional unit of income when the second earner works relatively to the case in which she is unemployed or out of the labor force.

${ }^{2}$ Fertility and child care facilities are mechanisms directly connected to the participation rate of women. Unfortunately, our dataset does not contain information on the geographical availability of childcare facilities, which could be a possible cause of the low participation rate of low-income mothers.

${ }^{3}$ The French system is characterized by the quotient familial, which has been adopted since 1945. It aims to make the amount of the income tax proportional to households' ability to pay. It consists of a coefficient by which the total household revenue has to be divided. It is a function of the number of household components, and each member has a different weight depending on being an adult or child. See Saint-Jaques (2009) for a detailed description of the French system.

${ }^{4}$ We consider Spain to be the country that most closely resembles Italy, both culturally and economically, but it exhibits an average tax wedge for married couples which is 10 percentage points lower than in Italy. Data are available from the OECD, Taxing Wages Comparative Tables (http://stats.oecd.org/Index.aspx?DataSetCode=AWCOMP).

${ }^{5}$ The complete table can be found in Additional file 1: Appendix B (Table 11).

${ }^{6}$ We are referring to the Decreto Legge 10/09/2003 n.276, Legge Biagi.

${ }^{7}$ See Table 12 in Additional file 1: Appendix B.

${ }^{8}$ The description of the data can be found in Section 3.2 and in Additional file 1: Appendix B.

${ }^{9}$ A particularly strong assortative matching effect in Italy could generate this positive correlation. However, it remains to explain why assortative matching is not relevant in other countries. For a discussion on this issue, see Marcassa (2014).

${ }^{10}$ As pointed out by Blundell and MaCurdy (1999) and Kleven et al. (2009), the labor supply of secondary earners is more elastic with respect to taxes than the labor supply of primary earners.

${ }^{11}$ The World Value Survey reports that 80 percent of the Italian population, of both genders, thinks that a child younger than 3 years old suffers if the mother works. Even though we recognize the importance of these variables in determining the labor supply decision, we do not include them in our analysis. 
${ }^{12}$ The average tax rate is the ratio between the total household taxes and the gross household income.

${ }^{13}$ The gross yearly earnings are chosen to represent the sample average, from Table 13, Additional file 1: Appendix B.

${ }^{14}$ The adoption of a discrete choice model is dictated by the evidence that, in Italy, institutional norms and demand-side rigidities imply concentrations around a limited number of hour choices (see del Boca (1999)).

${ }^{15}$ In our dataset (EU-SILC) each individual is observed for at most five years, thus not generating enough variation to provide a robust estimation of a dynamic model. We therefore rely on a simple static model, assuming that yearly wages are a sufficient statistic for the life cycle earnings profile.

${ }^{16}$ That corresponds to both one-person households and to the model where husbands' earnings are taken as given.

${ }^{17}$ This specification corresponds to the well known "Random utility model (RUM)".

${ }^{18}$ The residual $\epsilon$ cannot be interpreted as reflecting random preferences due to unobserved family characteristics. Otherwise, error terms would be correlated across alternatives. It is better to think of this term as describing observational errors, or possibly optimization errors or transitory departures from best choice by agents.

${ }^{19}$ EU-SILC provides two types of data: (1) cross-sectional data pertaining to a given time or a certain time period with variables on income, poverty, social exclusion and other living conditions; (2) longitudinal data pertaining to individual-level changes over time, observed periodically over a four years period.

${ }^{20}$ The results of the estimations are available upon request.

${ }^{21}$ Note that the tax burden is computed on imputed earnings. The static nature of the model allows us to consider the factors affecting earnings (e.g., accumulated experience) as exogenous.

${ }^{22}$ A simulation that does not take this into account shows that the joint tax system implies a revenue loss of about 18 percent, the working tax credit of about 2 percent, and the gender-based system of about 11 percent.

${ }^{23}$ See Buffeteau and Echevin (2003) for France, Steiner andWrohlich (2004) for Germany, and Aassve et al. (2007) for Italy.

${ }^{24}$ For example, in the WTC, households with two parents working at least 16 hours a week can obtain a reimbursement of 80 percent of the child care costs.

${ }^{25}$ We assume that the transfers for the first and second child are equal to the maximum amount of transfers guaranteed by the Italian tax system in the two cases.

${ }^{26}$ The results for the average and second earner taxation rate are relegated to Table 16 in Additional file 1: Appendix C.

${ }^{27}$ See the transition flows in Table 17 in Additional file 1: Appendix C.

${ }^{28}$ See Adema and Thévenon (2008) for a discussion of the existing policies directed to French families.

${ }^{29}$ The reduction of the population below the poverty line is also a target of Europe2020, the project of the European Commission.

${ }^{30}$ See http://epp.eurostat.ec.europa.eu/statistics_explained/index.php/Glossary: Equivalised_disposable_income.

${ }^{31}$ The poverty threshold is reported by Istat (2012).

\section{Additional file}

Additional file 1: Appendix. A Details of the Italian tax system. B Summary statistics. C Tables. D Figures. 


\section{Acknowledgements}

We would like to thank the participants to the Applied Economics Lunch Seminar at the Paris School of Economics, the lunch seminar at THEMA (Université de Cergy-Pontoise), several presentations at the Bank of Italy, Ugo Colombino, Juan F. Jimeno, Nezih Guner, Andrea Ichino, Julien Prat, Paola Profeta, the members of the Committee in charge of awarding the prize in memoriam of Etta Chiuri (2011), and an anonymous referee. All errors are ours.

A previous version of paper has been presented at the conference "Women and the Italian Economy" organized by the Bank of Italy, held in Rome on March 7th, 2012. The views expressed therein are those of the authors and do not necessarily reflect those of the Bank of Italy.

Responsible editor: Juan F. Jimeno

\section{Author details}

${ }^{1}$ Banca d'Italia, Economic Structure and Labor Market Division, Department for Structural Economic Analysis, via Nazionale 91, 00184 Roma, Italy. ${ }^{2}$ Université de Cergy-Pontoise THEMA (UMR CNRS 8184), 33 boulevard du Port, 95011 Cergy-Pontoise cedex, France.

Received: 12 August 2014 Accepted: 9 January 2015

Published online: 19 March 2015

\section{References}

Aaberge R, Colombino U, Strøm S (2000) Labor supply responses and welfare effects from replacing current tax rules by a flat tax: empirical evidence from Italy, Norway and Sweden. J Popul Econ 13:595-621

Aassve A, Pazienza M, Rapallini C (2007) Does Italy need family income taxation? No 77, Working Papers, ECINEQ, Society for the Study of Economic Inequality. Available at http://EconPapers.repec.org/RePEc:inq:inqwps:ecineq2007-77

Adema W, Thévenon O (2008) Les Politiques de Conciliation du Travail et de la Vie Familiale en France au Regard des Pays de I'OCDE. Rech et Prévisions Septembre 93:51-72

Alesina A, Ichino A, Karabarbounis L (2011) Gender-based taxation and the division of family chores. Am Econ J Econ Policy 3(2):1-40

Atkinson A (2011) The case for universal child benefit. In: Walker A, Sinfield A, Walker C (eds). Fighting Poverty, Inequality and Social Injustice. A Manifesto Inspired by Peter Townsend. Policy Press, Bristol

Bar M, Leukhina O (2009) To Work or Not to Work: Did Tax Reforms Affect Labor Force Participation of Married Couples? The B.E. Journal of Macroeconomics, De Gruyter 9(1):1-30

Blundell R, MaCurdy T (1999) Labor supply: A review of alternative approaches. In: Ashenfelter O, Card D (eds). Handbook of Labor Economics, edition 1, volume 3, chapter 27. Elsevier, Amsterdam. pp 1559-1695

Blundell R, Duncan A, McCrae J, Meghir C (2000) The labour market impact of the working families' tax credit. Fiscal Stud 21:75-103

Blundell R, Hoynes HW (2004) Has 'In-Work' Benefit Reform Helped the Labor Market?, NBER Chapters. In: Seeking a Premier Economy: The Economic Effects of British Economic Reforms, 1980-2000. National Bureau of Economic Research, Inc. pp 411-460

Blundell R, Bozio A, Laroque G (2011) Extensive and intensive margins of labour supply: working hours in the US, UK and France. IFS Working Papers W11/01. Institute for Fiscal Studies

Buffeteau S, Echevin D (2003) Taxation, marriage and labor supply: evidence from a natural experiment in France. Cahiers de recherche 0340. CIRPEE

Burtless G, Hausman J (1978) The effect of taxation on labor supply: evaluating the "Gary" negative income tax experiments. J Pol Econ 86:1103-1130

Cavalli M, Fiorio CV (2006) Individual vs family taxation: an analysis using tabeita04. Econpubblica Working Paper No. 118. Available at SSRN: http://ssrn.com/abstract=1338110 or http://dx.doi.org/10.2139/ssrn.1338110

Chote R, Emmerson C, Leicester A, Miles D (2007) The IFS green budget: January 2007. (IFS Commentaries C102). Institute for Fiscal Studies, London, UK

Colombino U, Del Boca D (1990) The effect of taxes on labor supply in Italy. J Hum Resour 25:390-414

Davis SJ, Henrekson M (2004) Tax Effects on Work Activity, Industry Mix and Shadow Economy Size: Evidence from Rich-Country Comparisons. Ratio Working Papers 57, The Ratio Institute

del Boca D (1999) Participation and fertility behavior of Italian women: the role of market rigidities. CHILD Working Papers 10/2000. CHILD - Centre for Household, Income, Labour and Demographic economics - ITALY

Eissa N, Kleven H, Kreiner CT (2005) Welfare Effects of Tax Reform, and Labor Supply at the Intensive and Extensive Margins, Tax Policy and Labor Market Performance. MIT Press, March 2005

Eissa N, Liebman JB (1996) Labor supply response to the earned income tax credit. Q J Econ 111:605-637

Ellwood D (2000) The impact of the earned income tax credit and social policy reforms on work, marriage, and living arrangements. Nat Tax J 53:1165-1186

Fang $H$, Keane M (2004) Assessing the impact of welfare reform on single mothers. Brookings Papers Econ Act 35:1-116 Hausman J (1980) The effect of wages, taxes, and fixed costs on women's labor force participation. J Publ Econ 14:161-194 Hausman JA (1985) Taxes and labor supply. In: Auerbach AJ, Feldstein M (eds). Handbook of Public Economics, edition 1, volume 1, chapter 4. Elsevier. pp 213-263

Heckman J (1979) Sample selection bias as a specification error. Econometrica 47:153-162

Immervoll H, Kleven HJ, Kreiner CT, Saez E (2007) Welfare reform in European countries: a microsimulation analysis. Econ J $117: 1-44$

Istat (2012) Poverty in Italy. Technical Report. Istat. Available at http://www.istat.it/en/archive/95933

Kleven HJ, Kreiner CT, Saez E (2009) The optimal income taxation of couples. Econometrica 77(2):537-560

Levy H, Lietz C, Sutherland H (2007) A guaranteed income for Europe's children? In: Jenkins S, Micklewright J (eds). Inequality and Poverty Re-examined. Oxford University Press, Oxford 
Marcassa S (2014) Unemployment duration of spouses: evidence from France. LABOUR: Rev Labour Econ Ind Relations 28(4):399-429

Meyer B, Rosenbaum D (2001) Welfare, the earned income tax credit, and the labor supply of single mothers. Q J Econ 116:1063-1114

Mooij R (2008) Reinventing the Dutch tax-benefit system: exploring the frontier of the equity-efficiency trade-off. Int Tax Public Finance 15:87-103

OECD (2010) Taxing wages 2008-2009. Special Feature: Non-Tax Compulsory Payments as an Additional Burden on Labour Income. Available at http://www.oecd.org/ctp/tax-policy/45120766.pdf

Olovsson C (2009) Why do Europeans work so little Int Econ Rev 50:39-61

Prescott EC (2004) Why do americans work so much more than Europeans? Q Rev Fed Reserv Bank Minneap:2-13

Rogerson R (2006) Understanding differences in hours worked. Rev Econ Dynamics 9:365-409

Saez E (2002) Optimal income transfer programs: intensive versus extensive labor supply responses. Q J Econ 117:1039-1073

Saint-Jaques G (2009) Individualization of taxes and tanfers and the labor supply decision of women: simulating the current French system and possible reforms. Masters APE Dissertation. Paris School of Economics, Septembre 2009

Saint-Paul G (2007) Against 'Gender-based taxation'. No 6582, CEPR Discussion Papers, C.E.P.R. Discussion Papers, http:// EconPapers.repec.org/RePEc:cpr:ceprdp:6582

Steiner V, Wrohlich K (2004) Household taxation, income splitting and labor supply incentives: a microsimulation study for Germany. Discussion Papers of DIW Berlin 421. DIW Berlin. German Institute for Economic Research

\section{Submit your manuscript to a SpringerOpen ${ }^{\circ}$ journal and benefit from:}

- Convenient online submission

Rigorous peer review

- Immediate publication on acceptance

- Open access: articles freely available online

- High visibility within the field

Retaining the copyright to your article

Submit your next manuscript at $\gg$ springeropen.com 